\title{
ELIMINATION OF INTRACANAL INFECTION IN DOGS' TEETH WITH INDUCED PERIAPICAL LESIONS AFTER ROTARY INSTRUMENTATION: INFLUENCE OF DIFFERENT CALCIUM HYDROXIDE PASTES
}

\author{
ELIMINAÇÃO DA INFECÇÃO INTRACANAL EM DENTES DE CÃES COM LESÕES \\ PERIAPICAIS INDUZIDAS APÓS INSTRUMENTAÇÃO AUTOMATIZADA - INFLUÊNCIA DE \\ DIFERENTES PASTAS DE HIDRÓXIDO DE CÁLCIO
}

Janir Alves SOARES ${ }^{1}$, Mário Roberto LEONARDO², Léa Assed Bezerra da SILVA³, Mário TANOMARU FILHO ${ }^{4}$, Izabel Yoko ITO ${ }^{5}$

1- DDS, MSc, PhD, Chairman, Discipline of Endodontics, Department of Dentistry, Federal University of Vales do Jequitinhonha e Mucuri, UFVJM, Diamantina, MG, Brazil.

2- DDS, MSc, PhD, Chairman, Department of Endodontics, Araraquara Dental School, UNESP, Araraquara, SP, Brazil.

3- DDS, MSc, PhD, Chairman, Discipline of Pediatric Dentistry, Department of Pediatric Clinic, Preventive and Social Dentistry, Ribeirão Preto Dental School, USP, Ribeirão Preto, SP, Brazil.

4- DDS, MSc, PhD, Associate Professor, Department of Endodontics, Araraquara Dental School, UNESP, Araraquara, SP, Brazil.

5- DDS, MSc, PhD, Chairman, Discipline of Microbiology, School of Pharmaceutical Sciences of Ribeirão Preto, USP, Ribeirão Preto, SP, Brazil.

Corresponding address: Janir Alves Soares - Universidade Federal dos Vales do Jequitinhonha e Mucuri - Rua da Glória, 187 - Diamantina-MG. Cep.: 39.100.000 - e-mail: janirsoares@citel1.com.br - Tel: (38) 35312901

Received: June 09, 2005 - Modification: March 09, 2006 - Accepted: May 2, 2006

\begin{abstract}
7 he

the antiseptic efficacy of rotary instrumentation associated with calcium hydroxide-based pastes prepared with different vehicles and antiseptics. Chronic periapical lesions were experimentally induced in 72 premolar root canals of four dogs. Under controlled asepsis, after initial microbiological sampling (A1), the root canals were instrumented using the ProFile system in conjunction with 5.25\% sodium hypochlorite and the intracanal medication was placed. Four experimental groups were formed according to the pastes used: group 1- Calen $(\mathrm{n}=18)$, group 2- Calen+CPMC $(\mathrm{n}=20)$, group 3- $\mathrm{Ca}(\mathrm{OH})_{2}$ p.a.+ anaesthetic solution $(\mathrm{n}=16)$ and group $4-\mathrm{Ca}(\mathrm{OH})_{2}$ p.a. $+2 \%$ chlorhexidine digluconate $(n=18)$. After 21 days, the pastes were removed; the canals were emptied and 96 hours later a second microbiological sample was obtained (A2). The incidence of positive microbiological cultures and the number of cfus in stages A1 and A2 were compared statistically by the Wilcoxon test while the influence of the different treatments in intracanal infection was evaluated by Kruskal-Wallis test at $5 \%$ significance level $(p<0.05)$. Large numbers of strict and facultative anaerobes, and viridans group streptococci were found in 100\% of root canals of A1 samples. Among A2 samples, all treatments showed significant reduction of cfus and positive cultures $(p<0.05)$, but only groups 3 and 4 showed $100 \%$ of root canals free of microorganisms. Rotary instrumentation plus $\mathrm{NaOCl} 5.25 \%$ associated with intracanal medication produced a drastic reduction or elimination of intracanal microbiota, whose performance was not influenced by the nature of the vehicle or the antiseptic added to the $\mathrm{Ca}(\mathrm{OH})_{2}$ p.a.

Uniterms: Calcium hydroxide; Microorganisms; Periapical lesions; Root canal therapy.
\end{abstract}

\begin{abstract}
RESUMO
objetivo deste estudo foi avaliar a eficácia anti-séptica da instrumentação rotatória associada às pastas à base de hidróxido de cálcio $\left[\mathrm{Ca}(\mathrm{OH})_{2}\right]$ contendo diferentes veículos e anti-sépticos. Lesões periapicais crônicas foram experimentalmente induzidas em 72 canais radiculares de pré-molares de 4 cães. Sob controlada assepsia, após amostras microbiológicas iniciais (A1), fez-se a instrumentação com o sistema ProFile coadjuvado pela solução de hipoclorito de sódio a 5,25\%, seguido de medicação intracanal. Em função das pastas utilizadas obtiveram-se 4 grupos: grupo 1- Calen $(\mathrm{n}=18)$, grupo 2- Calen+PMCC $(\mathrm{n}=20)$, grupo 3- $\mathrm{Ca}(\mathrm{OH})_{2}$ p.a.+ solução anestésica $(\mathrm{n}=16)$ e grupo 4- $\mathrm{Ca}(\mathrm{OH})_{2}$ p.a.+ solução de digluconato de clorexidina a 2\% (n=18). Transcorridos 21 dias, removeram-se as pastas, deixando os canais radiculares vazios e 96 horas após obteve-se a segunda amostragem microbiológica (A2). O número de unidades formadoras de colônias de microrganismos (ufc) e a incidência de culturas positivas antes e após cada tratamento foram analisados pelo teste de Wilcoxon enquanto a influência dos diferentes tratamentos na infecção intracanal foi avaliada pelo teste de Kruskal-Wallis com nível de signficância de 5,0\%. Verificaram-se nas amostras A1 elevadas quantidades de anaeróbios obrigatórios, facultativos e estreptococos do grupo viridans em 100\% dos canais radiculares. Nas amostras A2, todos os tratamentos proporcionaram significativa redução do número de ufc e de culturas positivas ( $<<0.05)$, mas somente os grupos 3 e 4 proveram $100,0 \%$ dos canais radiculares livres de microrganismos. Portanto, a instrumentação automatizada coadjuvada pela solução de hipoclorito de sódio a 5,25\% associada à medicação intracanal proporcionaram drástica redução ou eliminação da microbiota intracanal, cuja performance não foi influenciada pela natureza do veículo ou do anti-séptico acrescido ao hidróxido de cálcio p.a.

Unitermos: Hidróxido de Cálcio; Microrganismos; Lesões periapicais; Tratamento de canal radicular.
\end{abstract}




\section{INTRODUCTION}

Microorganisms are the major agents responsible for the persistence of periapical lesions associated with root canals with necrotic pulps or with previous unsuccessful endodontic treatment ${ }^{27}$. In view of this, one of the main goals of endodontic treatment is the elimination of infection in the root canal system before obturation ${ }^{4,24}$. Biomechanical preparation causes a major antiseptic impact on the endodontic microbiota ${ }^{21,26}$ because simultaneous debridement and modeling ${ }^{26}$ produced by the cutting action of files and the bactericidal effect of the flux of irrigation solutions and aspiration, eliminate most viable microorganisms in the main root canal ${ }^{17,23,30}$. Overall, the complex anatomy of root canals together with the polymicrobial nature and diffusion of infection through the root canal system ${ }^{9,27}$ limit the antiseptic efficacy of instrumentation ${ }^{23,24,25}$. Consequently, after meticulous cleaning and shaping of the root canals, the use of calcium hydroxide-based pastes as intracanal dressings has been recommended to reduce or eliminate any residual infection due to its high alkalinity ${ }^{3,14,21,25}$. However, several questions concerning calcium hydroxide intracanal medication remain unanswered, for example: 1) How long should they remain in the root canal? 2) What is the best vehicle to be used? and, 3) Is there the need to incorporate an antiseptic?

Based on the pattern of diffusion of hydroxide ions to the most external layers of root dentin, the minimum time would be between 14 and 21 days ${ }^{12}$. Either aqueous or viscous water-soluble inert vehicles have been the most commonly used ${ }^{21}$. However, the neutralizing action of dentin towards hydroxyl ions ${ }^{15}$ and the relative resistance of some organisms to certain levels of alkalinity ${ }^{5}$ makes calcium hydroxide inefficient against some microorganisms in dentinal tubules ${ }^{13,19,20}$, which would justify the addition of other antiseptics ${ }^{9,19}$.

The advent of rotary instrumentation with nickel-titanium files has improved the preparation of root canals ${ }^{17,22}$. Therefore, the goal of this study was to evaluate the antiseptic efficacy of nickel-titanium rotary instrumentation used with 5.25\% sodium hypochlorite irrigation, followed by the long-term application of calcium hydroxide dressings prepared with either, aqueous or viscous water-soluble vehicles, inert or with antiseptic properties, in root canals of dogs' teeth with induced chronic periapical lesions.

\section{MATERIALS AND METHODS}

Chronic periapical lesions were experimentally induced in 72 premolars of four 1-year-old dogs.

For sedation $2.0 \mathrm{~mL}$ Rompum (Bayer S/A - Produtos veterinários - Ind. Bras., RS, Brazil) was injected intramuscularly at a dose of $3.0 \mathrm{mg} / \mathrm{Kg}$ body weight. For general anesthesia, on average, $4 \mathrm{~mL}$ solution of Thiopental (Thionembutal-Abbott Laboratórios do Brasil Ltda., RJ) was injected intravenously at a dose of $30 \mathrm{mg} / \mathrm{Kg}$ body weight. A coronal access cavity was created with a \#2 Endo Access bur. Based on diagnostic periapical radiograph, the root canals were explored with \#15 and \#20 K-files (K-Flexofile Dentsply Maillefer, Ballaigues, Switzerland) until reaching the apical plateau, situated approximately $1.5 \mathrm{~mm}$ before the radiographic apex. After odontometric radiograph, the root canal pulp was extirpated with a \#25 Hedströem file. Subsequently, the apical delta was progressively enlarged to a \#30 K-file. The root canals remained exposed to the oral environment for 6 days after which the coronal entrances were sealed.

After a maximum of 90 days, well-defined periapical radiolucent areas were observed, suggestive of chronic periapical lesions. The procedures of root canal treatment were maintained under rigorous antiseptic conditions. After complete rubber dam isolation, antisepsis of the operative field was performed swabbing with $0.3 \%$ iodated alcohol neutralized with alcohol/ether, followed by removal of the coronal seal. In sequence, the first microbiological sample of the root canals was obtained (A1), using three \#25 sterile absorbent paper points of diameter, provided with metal wings. The points were introduced sequentially into the canals up to the apical third for 1 minute and subsequently transferred to test tubes containing $1.5 \mathrm{~mL}$ of reduced transport fluid (RTF). Then, sequentially, the exploration/ neutralization of the necrotic/septic content of the cervical two-thirds of the root canals was undertaken manually using a \#20 K-file in combination with 5.25\% sodium hypochlorite irrigation. Rotary instrumentation was then carried out using the ProFile System (Dentsply/Tulsa Dental Products, Tulsa, OK, USA). Orifice shapers were used for preflaring of the cervical two-thirds and nickel-titanium files with 0.04 and 0.06 tapers were used for apical preparation. Next, \#0.30 to $\# 0.60 \mathrm{~mm}$ files were used according to a crown-down technique. Copious irrigation with $3.6 \mathrm{~mL}$ of $5.25 \%$ sodium hypochlorite was done at each change of file using a syringe and 27G needle (Gengibrás -27G Ibras CBO Ind. Bras., SP) introduced close to the working length. Exploration/ neutralization of the apical third was completed with a \#30 K-file and the progressive enlargement of this segment up to \#45 or \#60 K-files established an apical stop $1.5 \mathrm{~mm}$ from the radiographic apex, with foramen debridement with a \#30 K-file.

After removal of the smear layer and drying of the canals, the calcium hydroxide-based pastes, all containing watersoluble aqueous (anesthetic solution or $2 \%$ chlorhexidine digluconate) or viscous (polyethylene glycol) vehicles, were applied. Four experimental groups were formed according to the intracanal medication used: group $1(n=18)$ : canals were filled with Calen paste (S.S. White Artigos Dentários Ltda. Rio de Janeiro, RJ, Brasil); group $2(n=20)$ : Calen paste associated with camphorated paramonochlorophenol (Calen/CPMC; S.S. White Artigos Dentários Ltda.); group 3 $(\mathrm{n}=16)$ : paste prepared with $\mathrm{Ca}(\mathrm{OH})_{2}$ p.a. and an anaesthetic solution - Citanest 3\% with octapressin - (prilocaine hydrochloride $30 \mathrm{mg} / \mathrm{mL}$ and felypressin $0.03 \mathrm{IU} / \mathrm{mL}$ - Astra Química e Farmacêutica, São Paulo, SP, Brazil); and group 4 $(\mathrm{n}=18): \mathrm{Ca}(\mathrm{OH})_{2}$ p.a. plus $2 \%$ aqueous solution of chlorhexidine digluconate (FGM Produtos Odontológicos, 
Joinville, SC, Brazil). Calen paste is composed of $2.5 \mathrm{~g}$ calcium hydroxide, $0.5 \mathrm{~g}$ zinc oxide, 0.05 g colophony, $2 \mathrm{~mL}$ polyethylene glycol 400 (vehicle). Calen pasta /CPMC is formed by the addition of $0.15 \mathrm{~mL}$ camphorated paramonochlorophenol to Calen paste. Calcium hydroxide p.a. powder (Labsynth Ltda, Diadema, SP, Brazil) used in groups 3 and 4 was weighed on an analytic balance and mixed to the respective solutions at a ratio of $0.9 \mathrm{~g} / \mathrm{mL}$. Calen and Calen/CPMC pastes were applied with an ML syringe (S.S.White Artigos Dentários Ltda.) and a $27 \mathrm{G}$ needle, while the other two pastes were applied with a \#4 spiral lentulo at low-speed. Coronal sealing was done with zinc oxide eugenol cement.

After 21 days, the access cavities were opened and the dressings were removed by copious irrigation of $5 \mathrm{~mL}$ of anionic detergent solution and stirring with \#45 or \#60 Kfiles. The canals were dried, left empty and were coronally sealed. The second microbiological sample (A2) was obtained from the root canals 96 hours later. The microbiological samples were suspended in liquid by mechanical vibration in a Mixtron-Toptronix apparatus (São Paulo, SP, Brazil) for 2 minutes, and then the bacterial suspension was diluted in a $1 / 15 \mathrm{M}$ saline solution containing phosphate buffered solution (PBS), pH 7.0, in a decimal series dilution to $10^{-4}$, in a laminar flow hood. Aliquots of $0.05 \mathrm{~mL}$ were placed in plates containing the following culture media: blood agar (As); enriched blood agar (AsK); Mitis salivarius agar (Ms); sucrose bacitracin agar (SB20); MacConkey agar (Mc) and hypertonic egg yolk agar (Ni). The aliquots were spread with a glass rod in an L-shape. Approximately $3.0 \mathrm{~mL}$ of tioglycolate broth (Tio's) without indicator or dextrose (Difco, Detroit, MI, USA) was added to the tubes containing the remaining suspension. Anaerobic incubation was done for 7 days in gas-pack jars; microaerophilic in a closed jar with a lit candle and aerobic for 48 hours at $37^{\circ} \mathrm{C}$. The blood agar was enriched with hemin $(5 \mathrm{mg} / \mathrm{mL})$ and menadione (0.5 mg/mL), denominated AsK, and was used to retrieve strict anaerobic microorganisms. The Ms medium allowed the growth of viridans group streptococci (S. sanguis, $S$. mitis, S. salivarius and S. mutans). Ni, SB20 and Mc media allowed the growth of Staphylococcus aureus, mutans group streptococci and gram-negative enteric facultative bacilli, respectively. The colony forming units (cfus) of microorganisms were identified under stereomicroscopy (Nikon, Tokyo, Japan). The incidence of positive microbiological cultures and the number of cfus in stages A1 and A2 were statistically compared using the Wilcoxon test while the influence of the different treatments in intracanal infection was evaluated by Kruskall-Wallis test at $5 \%$ significance level $(\mathrm{p}<0.05)$.

\section{RESULTS}

The microbiological conditions of the root canals from stages A1 and A2 are summarized in Tables 1, 2 and 3.

Examination of A1 samples showed the four groups with similar microbiological conditions ( $\mathrm{p}>0.05$ ), i.e., large numbers of cfus of strict and facultative anaerobes and viridans group streptococci were retrieved. Groups 1 and 2 showed black-pigmented anaerobic rods in samples 1 and 3 , respectively, while two samples of group 3 were positive for aerobic gram-negative enteric bacteria. Examination of A2 samples showed a significant reduction in the numbers of cfus and positive cultures were also observed $(\mathrm{p}<0.05)$, which were not influenced by the different treatments

TABLE 1- Cfus means of microorganisms before endodontic treatment (A1) and 4 days after the removal of the calcium hydroxide-based pastes (A2)

\begin{tabular}{|c|c|c|c|c|c|c|}
\hline \multirow[t]{2}{*}{ Groups } & \multicolumn{3}{|c|}{ Stage A1 } & \multicolumn{3}{|c|}{ Stage A2 } \\
\hline & $\begin{array}{c}\text { Strict } \\
\text { anaerobes }\end{array}$ & Aerobes & $\begin{array}{l}\text { viridans group } \\
\text { streptococci }\end{array}$ & $\begin{array}{c}\text { Strict } \\
\text { Anaerobes }\end{array}$ & Aerobes & $\begin{array}{c}\text { viridans group } \\
\text { streptococci }\end{array}$ \\
\hline Calen & 1.276 .579 & 463.372 & 235.945 & 31.1 & 4.4 & 0 \\
\hline Calen/CPMC & 2.862 .968 & 165.068 & 41.126 & 0 & 0 & 0 \\
\hline $\begin{array}{l}\mathrm{Ca}(\mathrm{OH})_{2} \text { p.a.+ } \\
\text { anesthetic }\end{array}$ & 1.237 .245 & 68.812 & 33.604 & 0 & 0 & 0 \\
\hline $\begin{array}{l}\mathrm{Ca}(\mathrm{OH})_{2} \text { p.a.+ } \\
\text { chlorhexidine }\end{array}$ & 1.690 .978 & 88.931 & 77.153 & 0 & 0 & 0 \\
\hline
\end{tabular}

TABLE 2- Percentage of microbial reduction (cfus) for A2 sampling

Groups Calen Calen/CPMC $\mathrm{Ca}(\mathrm{OH})_{2}$ p.a. + anesthetic $\mathrm{Ca}(\mathrm{OH})_{2}$ p.a. + chlorhexidine

Percentage of

$\begin{array}{llll}\text { Microbial reduction } & 99.99 \% & 100.0 \% & 100.0 \%\end{array}$


(p>0.05), although only in groups 3 and 4 in which root canals completely free of microorganisms were found. Clinically, a fistula developed in groups 1,3 and 4 but healed during endodontic treatment. All samples were negative for mutans group streptococci.

\section{DISCUSSION}

With the methodology employed in this study, all teeth developed well-defined radiolucent periapical areas associated to root canals from which microorganisms were retrieved in numbers equivalent to those found in human root canals ${ }^{4,24}$. Among the prognostic factors, periapical lesions have a negative impact on the success of endodontic treatment, mainly when there are viable microorganisms in the root canals at the moment of obturation ${ }^{4,24,27}$.

Regardless of the files used, stainless steel or nickeltitanium, the technique of instrumentation, manual or mechanized, the pattern of apical enlargement, the chemical group or concentration of the irrigation solution used, the antisepsis obtained from biomechanical preparation is temporary and partial ${ }^{17,22,23,25,30}$. Furthermore, its relative antiseptic efficacy depends on the interaction of mechanical, chemical and physical factors, such as the diameter of root canal enlargement, the type, concentration and quantity of irrigant, and the frequency of irrigations ${ }^{17,25,26,28,30}$. Because the root canals of young dogs' teeth have smooth apical curvatures of average diameter, satisfactory root canal shaping was obtained in the present study by apical enlargement up to diameters \#0.45-\#0.60mm and conicity of $0.06 \mathrm{~mm} / \mathrm{mm}$. A titrated concentration of $5.25 \%$ sodium hypochlorite was used for irrigation, and $3.6 \mathrm{~mL}$ were flushed into the canals at each change of file up to the working length with light pressure to obtain a flux of irrigant along the length of the canal. Obviously, this pattern of instrumentation maximizes the reduction of intracanal microbiota, leaving residual microorganisms in the root canal and other sites of the root canal system to be eliminated in the complementary antiseptic stage.

The use of calcium hydroxide dressing as an intracanal medication has been widely recommended because in addition to its bactericidal action, calcium hydroxide neutralizes bacterial toxins, is biocompatible with the periapical tissues, inhibits inflammatory root and bone resorption and stimulates periapical regeneration ${ }^{8,9,17,25,26}$. Its antimicrobial action is due to high alkalinity (pH12-13). The hydroxide ions act directly and irreversibly on molecules essential to the bacterial metabolism and reproduction, such as structural proteins and enzymes, nucleic acids, phospholipids and unsaturated fatty acids. Additionally, the physical filling of the root canal inhibits the influx of nutrients and microbial recolonization ${ }^{21}$. Other substances in the pastes with an antiseptic action were CPMC and 2\% chlorhexidine digluconate. Polyethylene glycol, anaesthetic solution, colophony and zinc oxide are considered inert. The bactericidal effect of CPMC is due to inactivation of the sulfhydryl groups of oxidases and dehydrogenases by chlorine and phenyl groups and the denaturation of proteins of the bacterial cell membrane ${ }^{20}$. Chlorhexidine is a cationic molecule that links to the anionic bacterial cell wall altering permeability. At low concentrations, it has a bacteriostatic effect due to the loss of low weight molecules and ions, while at high concentrations it is bactericidal, causing precipitation or coagulation of cytoplasm, probably due to rupture of cross-links of proteins or interaction with phosphate groups present in adenosine phosphates and nucleic acids ${ }^{7}$.

In vitro studies have shown that when in direct contact, calcium hydroxide eliminated all microorganisms present in the root canals in periods that varied from minutes to few days ${ }^{3,11,20}$. However, in vivo studies have not reported similar performance in the root canal system $9,13,14,20,25,26$. The relative reduction or inefficacy of antiseptics must be due to several

TABLE 3- Microbiological conditions of the root canals in Tio's medium in A1 and A2

\begin{tabular}{|c|c|c|c|c|}
\hline \multirow[t]{3}{*}{ Groups } & \multicolumn{2}{|c|}{ Stage A1 } & \multicolumn{2}{|c|}{ Stage A2 } \\
\hline & Positive & Negative & Positive & Negative \\
\hline & Cultures & Cultures & Cultures & Cultures \\
\hline $\begin{array}{l}\text { Calen } \\
(n=18)\end{array}$ & $18(100.0 \%)$ & 0 & $3(16.7 \%)$ & $15(83.3 \%)$ \\
\hline $\begin{array}{l}\text { Calen/CPMC } \\
(n=20)\end{array}$ & $20(100.0 \%)$ & 0 & $2(10.0 \%)$ & $18(90.0 \%)$ \\
\hline $\begin{array}{l}\mathrm{Ca}(\mathrm{OH})_{2} \text { p.a.+ } \\
\text { anesthetic } \\
(\mathrm{n}=16)\end{array}$ & $16(100.0 \%)$ & 0 & 0 & $16(100.0 \%)$ \\
\hline $\begin{array}{l}\mathrm{Ca}(\mathrm{OH})_{2} \text { p.a.+ } \\
\text { chlorhexidine } \\
(\mathrm{n}=18)\end{array}$ & $18(100.0 \%)$ & 0 & 0 & $18(100.0 \%)$ \\
\hline
\end{tabular}


factors that include the presence of organic material and the neutralizing effect of dentin on the hydroxyls ${ }^{15}$ and to the particular resistance of some bacteria to certain levels of alkalinity $^{5}$. An alternative strategy consists of adding an antiseptic to calcium hydroxide, for example CPMC, which is effective against microorganisms resistant to calcium hydroxide ${ }^{19,20}$. Another antimicrobial, chlorhexidine digluconate, has been evaluated in liquid and gel forms ${ }^{16}$, as an irrigant ${ }^{6,10,29}$ or intracanal medication ${ }^{2,16}$ in concentrations that vary from 0.2 to $5 \%$, alone or combined with calcium hydroxide ${ }^{16,18}$. This substance has a wide spectrum of antimicrobial action ${ }^{6,10}$, penetrating substantivity ${ }^{10,29}$ and diffuses through dentin ${ }^{1}$.

Long-term dressings remain for 21 days in root canals, the minimum time necessary for hydroxyl ions to reach by diffusion, stable levels of alkalinity in the most external layers of root dentin ${ }^{12}$. After meticulous removal of the intracanal medication, the root canals were evaluated microbiologically 96 hours later. During this time, microorganisms remaining in the root canal system could proliferate and recolonize the main root canal, reaching numbers equivalent to those found prior to endodontic treatment ${ }^{3,4,24}$. Samples taken immediately after antiseptic procedures provide many false-negative results. However, negative microbiological cultures 4 days after the removal of intracanal dressing indicated that there was marked antiseptic activity, similar to the results found in this study, especially in root canals treated with calcium hydroxide in combination with anaesthetic solution or chlorhexidine digluconate.

In clinical studies with patients, the complementary application of antiseptic and calcium hydroxide paste is associated with negative cultures in the order of $92.5 \%$ to $100 \%^{3,4,14,24,27}$. Although the endodontic microbiota of dogs is unknown in terms of species, quantitatively it is equivalent to human root canals ${ }^{25,26}$. Thus, in the present study, the percentage of negative cultures ranged from $83.3 \%$ to $100 \%$ while microbial reduction varied from $99.99 \%$ to $100 \%$. Statistically, the different endodontic treatments offered similar antisepsis of root canals, regardless of whether the vehicle used for preparation of the calcium hydroxide pastes was viscous or aqueous, inert or bactericidal. Nevertheless, the aqueous vehicle was slightly superior.

After treatment with the Calen paste, there were three positive samples. One of the samples was not quantifiable $(<20 \mathrm{ufc} / \mathrm{mL}$ ) and in the other two the percentage reduction was $99.99 \%$. However, there was a larger number of strict anaerobes in the initial samples of root canals treated with Calen/CPMC paste. After endodontic treatment, there was $100 \%$ reduction in the numbers of cfus and only two root canals $(10 \%)$ contained unquantifiable microorganisms. In the root canals treated with an association of anaesthetic or chlorhexidine digluconate there was a complete absence of microorganisms, which means that calcium hydroxide associated with an aqueous vehicle, either inert or bactericidal, was proven an excellent intracanal antiseptic. These results could be attributed to the greater velocity of ionic dissociation of calcium hydroxide by the anaesthetic solution and/or antiseptic synergism with chlorhexidine.
Although it is a challenge to obtain sterilization of the root canal system in vivo, it is possible to obtain $94-96 \%$ clinical and radiographic success rate ${ }^{4,24,27}$ due to the elimination or significant reduction of the intracanal microbiota to undetectable levels using current culture techniques ${ }^{24,25}$. For treatment of teeth with necrotic pulps and chronic periapical lesions, rotary instrumentation associated with placement of calcium hydroxide intracanal medication for 21 days may offer the ideal antiseptic conditions for root canal obturation.

\section{CONCLUSIONS}

1-The root canals of dogs' teeth associated with experimentally induced chronic periapical lesions showed large numbers of colony forming units of strict facultative aerobic microorganisms and viridans group streptococci.

2-Rotary instrumentation in conjunction with 5.25\% $\mathrm{NaOCl}$ irrigation followed by the use of calcium hydroxidebased pastes for 21 days produced marked intracanal antisepsis.

3-Chlorhexidine digluconate was shown to be an adequate vehicle for calcium hydroxide pastes.

4-Although no statistically significant difference was found, only the combination of rotary instrumentation and 5.25\% NaOCl irrigation associated with calcium hydroxide in an aqueous vehicle resulted in microbial elimination in $100 \%$ of the root canals.

\section{REFERENCES}

1-Almyroudi A, Mackenzie D, Mchugh S, Saunders WP. The effectiveness of various disinfectants used as endodontic intracanal medications: an in vitro study. J Endod. 2002;28:163-7.

2-Barthel C R, Zimmer S, Zilliges S, Schiller R, Göbel UB, Roulet J-F. In situ antimicrobial effectiveness of chlorhexidine and calcium hydroxide: gel and paste versus guta-percha points. J Endod. 2002;28:427-30

3-Bystrom A, Sundqvist G. The antibacterial effect of camphorated paramonochlorophenol, camphorated phenol and calcium hydroxide in the treatment of infected root canals. Endod Dent Traumatol. 1985; 1:170-5.

4-Bystrom A, Happonen RP, Sjögren U, Sundqvist U. Healing of periapical lesions of pulpless teeth after endodontic treatment with controlled asepsis. Endod Dent Traumatol. 1987;3:58-63.

5-Evans M, Daviesd JK, Sundgvist G, Fidgor D. Mechanisms involved in the resistance of Enterococcus faecalis to calcium hydroxide. Int Endod J. 2002;35:221-8.

6-Jeansonne MJ, White RR. A comparison of 2.0\% chlorhexidine gluconate and $5.25 \%$ sodium hypochlorite as antimicrobial endodontic irrigants. J Endod. 1994;20:276-8.

7-Jenkins S, Addy M, Wade W. The mechanism of action of chlorhexidine - A study of plaque growth on enamel inserts in vivo. J Clin Periodontol. 2002;15:415-24. 
8-Leonardo MR, Silva LAB, Leonardo RT, Utrilla LS, Assed S. Histological evaluation of therapy using a calcium hydroxide dressing for teeth with incompletely formed apices and periapical lesions. J Endod. 1993;19:348-52.

9-Leonardo MR, Almeida WA, Ito IY, Silva LAB. Radiographic and microbiologic evaluation of posttreatment apical and periapical repair of root canals of dogs' teeth with experimentally induced chronic lesion. Oral Surg Oral Med Oral Pathol Oral Radiol Endod. 1994;78:232-8.

10-Leonardo MR, Tanomaru Filho M, Silva LAB, Nelson Filho P, Bonifácio KC, Ito IY. In vivo antimicrobial activity of $2 \%$ chlorhexidine used as a root canal irrigating solution. J Endod 1999;25:167-71.

11-Leonardo MR, Silva LAB, Tanomaru Filho M, Bonifácio KC, Ito IY. In vitro evaluation of antimicrobial activity of sealers and pastes used in Endodontics. J Endod. 2000;26:391-4.

12-Nerwich A, Fidgor D, Endo D, Messer HH. pH changes in root dentin over a 4-week period following root canal dressing with calcium hydroxide. J Endod. 1993;19:302-6.

13-Orstavik D, Haapasalo M. Disinfection by endodontic irrigants and dressings of experimentally infected dentinal tubules. Endod Dent Traumatol. 1990;6:142-9.

14-Orstavik D, Kerekes K, Molven O. Effects of extensive apical reaming and calcium hydroxide dressing on bacterial infection during treatment of apical periodontitis: a pilot study. Int Endod J. $1991 ; 24: 1-7$.

15-Portenier I, Haapasalo H, Rye A, Waltino T, Orstavik D, Haapasalo M. Inactivation of root canal medicaments by dentine, hydroxyapatite and bovine serum albumin. Int Endod J. 2001;34:184-

16-Quillin B, Dabirsiaghi CL, Krywolap GN, Dumsha TC Antimicrobial effect of $\mathrm{Ca}(\mathrm{OH})_{2}$ supplemented with metronidazole and chlorhexidine as intracanal medicaments. (poster clinic no.15). J Endod. 1992;18:187.

17-Shuping GB, Orstavik D, Sigurdsson A, Trope M. Reduction of intracanal bacteria using nickel-titanium rotary instrumentation and various medications. J Endod. 2000;26:751-5.

18-Silva LAB, Nelson-Filho P, Leonardo MR, Rossi MA, Pansan CA. Effect of calcium hydroxide on bacterial endotoxin in vivo. J Endod. 2002;28:94-8

19-Siqueira Jr JF, Uzeda M. Disinfection by calcium hydroxide pastes of dentinal tubules infected with two obligate and one facultative anaerobic bacteria. J Endod. 1996;22:674-6.

20-Siqueira JF Jr, Uzeda M. Influence of different vehicles on the antibacterial effects of calcium hydroxide. J Endod. 1998;24:663-5.

21-Siqueira Jr JF, Lopes HP Mechanisms of antimicrobial activity of calcium hydroxide: a critical review. Int Endod J. 1999;32:361-9.

22-Siqueira Jr JF, Lima KC, Magalhães FAC, Lopes HP, Uzeda M. Mechanical reduction of the bacterial population in the root canal by three instrumentation techniques. J Endod. 1999;25:332-5.

23-Siqueira JF Jr, Rôcas IN, Favieri A, Lima KC. Chemomechanical reduction of the bacterial population in the root canal after instrumentation and irrigation with $1 \%, 2,5 \%$, and 5,25\% sodium hypochlorite. J Endod. 2000;26:331-4.

24-Sjögren U, Fidgor D, Persson S, Sundqvist G. Influence of infection at the time of root filling on the outcome of endodontic treatment of teeth with apical periodontitis. Int Endod J. 1997;30:297-306.
25-Soares JA, Leonardo MR, Tanomaru Filho M, Silva LAB, Ito IY. Influência do preparo biomecânico e da medicação intracanal na anti-sepsia dos canais radiculares. RBO. 2004;61:96-9.

26-Soares JA, Leonardo MR, Tanomaru Filho M, Silva LAB, Ito IY. Effect of biomechanical preparation and calcium hydroxide pastes on the anti-sepsis of root canal systems in dogs. J Appl Oral Sci. 2005,12:110-7.

27-Sundqvist G, Fidgor D, Persson S, Sjögren U. Microbiological analysis of teeth with failed endodontic treatment and the outcome of conservative re-treatment. Oral Surg Oral Med Oral Pathol Oral Radiol Endod. 1998;85:86-93.

28-Usman N, Baumgartner JC, Marshall JD. Influence of instrument size on root canal debridment. J Endod. 2004;30:110-2.

29-White RR, Hays GL, Janer LR. Residual antimicrobial activity canal irrigation with chlorhexidine. J Endod. 1997;23:229-31.

30-Yared GM, Bou Dagher FE. Influence of apical enlargement on bacterial infection during treatment of apical periodontitis. J Endod. 1994;20:535-7. 